\title{
A cross sectional study of nutritional status among a group of school children in relation with gingivitis and dental caries severity
}

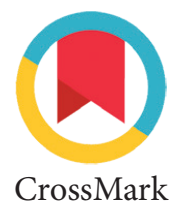

\author{
Muhammad H. Achmad, ${ }^{*}$ Andi M. Adam, ${ }^{2}$ Anni Satria ${ }^{2}$
}

\section{Abstract}

Objective: Generally, the problem of children nutritional status is the impact of imbalance intake and output of nutrients (nutritional imbalance). This condition can easily cause dental caries, especially in school children. The aim of this study was to determine nutritional status among a school children of Barru Regency, South Sulawesi, Indonesia, in relation with gingivitis and dental caries severity.

Material and Methods: A total of 127 school children in the age range of 9-12 years from Barru Regency were included in this study as a sample of simple random sampling with cross-sectional study. Nutritional status of children (BMI index), degree of gingival inflammation (using chi-square test statistic), and missing teeth (DMF-T index) were recorded. Additional information was collected using a questionnaire survey regarding knowledge about dental health, dietary habits, and oral health behaviors.

Results: A group of who severe underweight (102 children), had higher odds for mild gingivitis (GI 79.4\%) than others group of who has an ideal weight (16 children), had mild gingivitis (GI 62.5\%). Children, who severe underweight, had higher odds for moderate caries (38.2\%) than others group of who has an ideal weight, had moderate caries (18.8\%). Based on chi-square test, there are correlation of nutritional status and dental caries severity $(p=0.000<p=0.05)$.

Conclusion: There is a relationship of nutritional status with gingivitis and dental caries severity among a school children.
'Departement of Pediatric, Faculty of Dentistry, Hasanuddin University, Makassar, Indonesia ${ }^{2}$ Department of Periodontic, Faculty of Dentistry, Hasanuddin University, Makassar, Indonesia

\footnotetext{
${ }^{*}$ Correspondence to: Muhammad H. Achmad, Departement of Pediatric, Faculty of Dentistry, Hasanuddin University putrykhairunnisa26@gmail.com
}

Received:10 September 2016 Revised: 15 November 2016 Accepted: 22 November 2016 Available Online: 18 December 2016

Keywords: Gingivitis, Nutritional status, Periodontitis

Cite this Article: Achmad MH, Adam AM, Satria A. 2016. A cross sectional study of nutritional status among a group of school children in relation with gingivitis and dental caries severity. Journal of Dentomaxillofacial Science 1(3): 150-154. D0I: 10.15562/jdmfs.v1i3.307

\section{Introduction}

Oral health is one of public health issues require a comprehensive treatment because its wide dimensions that need immediate treatment. In range age of 9-12 years old is the period where the replacement process of primary teeth to permanent teeth is still ongoing. ${ }^{1}$

Nutrition is the sum total of all the processes by which an organism takes in by normal consume of food through digestion, absorption, transport, storage, metabolism and spending unused substances to sustain life, growth and normal function of organs and supply energy. While the nutritional status is an expression of balance situation in a form of certain variables, or the embodiment of nutrien certain variables. $^{2}$

Generally, the problem of children nutritional status is the impact of imbalance intake and output of nutrients (nutritional imbalance), the situation where intake of more than output, or misconduct in choosing and consuming food. Those impact was caused by chronic disease, over or less of weight, dental caries, or allergic etc. Bacteria's in the mouth will change to acids and concentrate on the tooth surface or in between the teeth with materials that are removed from the body of the bacteria, Saliva, food and the surface of tooth provide protection for the bacteria in the mouth to keep and form a colon ${ }^{3}$

School-age is a period of growth phase where the physical activity increased, such as playing and exercising. This phase need a high nutrient intake to be full-filled the nutrition need. The growth of children depends on the quantity and the quality of nutrients. ${ }^{4}$

Dental caries is an infection which damaged tooth surface. This infection caused tooth cavity and pain, tooth loss infection and various dangerous cases. Dental caries is caused by four connected components those are: tooth and saliva include tooth structure and morphology, position of the tooh, salivary $\mathrm{pH}$, the quantity of saliva, saliva viscosity, microorganism in the mouth which produces acids through fermentation eg, streptococcus, lactobacillus, food contains carbohydrates eg sucrose and glucose that can be fermented by certain bacteria to form acids, the component of time. ${ }^{5}$

Caries can be prevent by dietary habit, plaque control, or oral hygiene examination. Oral hygiene will direct a person to hygiene and healthy behavior. Cavity is pathological process that involves damaged 
of tooth enamel and lack of calcium. Inability to do oral care or oral hygiene can cause dental caries. ${ }^{6}$

Gingivitis is a inflammation reaction of gingival or gums which caused by biofilm accumulation of plaque along the gingival margin and the host inflammatory response to bacterial products. The clinical symptoms of gingivitis is characterized by a change of color, change of shape, change in consistency (firmness), change of texture and bleeding on gums.?

Gingivitis occurs due to inadequate oral hygiene are usually characterized by redness, swelling and bleeding tendency of the gingiva. There are some factors of gingivitis such as, plaque and calculus deposits on the surface of the teeth, food tucked, cavities, tooth restorations hanging edge and dental fillings are not fit. One experimental gingivitis

$11.8 \%$

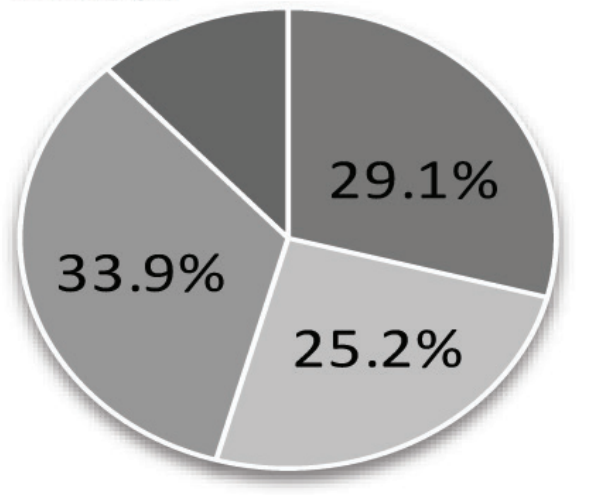

Figure 1 Distribution of sample by age

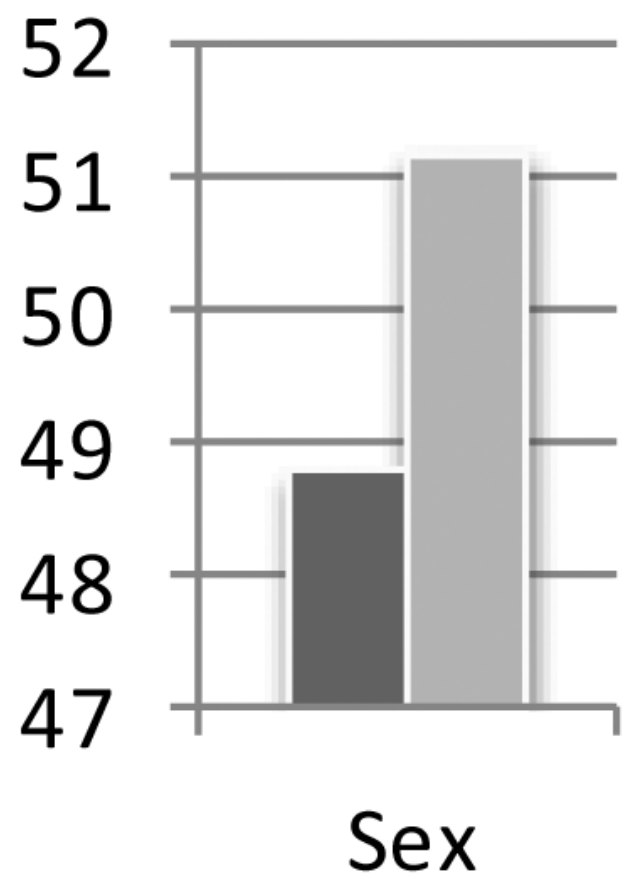

Figure 2 Distribution of sample by sex study showed that the accumulation of plaque on gingival have a very strong impact in the occurrence of gingivitis. Several epidemiological studies indicate that gingivitis of varying severity is generally found in children and adolescents. The prevalence of gingivitis in children increases with age until it reaches the peak of puberty. The prevalence of gingivitis in children range aged 5-14 years in Rajasthan (India) approximately $84.37 \%{ }^{8}$

This study aims to determine nutritional status among a school children of Barru Regency, South Sulawesi, Indonesia, in relation with gingivitis and dental caries severity.

\section{Material and Methods}

The type of research is observational analytic by cross-sectional study. The population of the study was the children of elementary school in age 9-12 years in the sub district of Tanete Rilau, Barru. The sample of research has caries and gingivitis. Exclusion criteria were samples that suddenly refuse to be the subject of research. The sampling is done by simple random sampling with a total of 127 children .

Data were collected through field observation. And researcher performed oral examination to identify dental caries and gingivitis. After the sample be obtained, then the weight and height measurement in children's nutritional status. Results are recorded on the examination sheet. Data were processed using the program Statistical Package for the Social Sciences (SPSS).

According to WHO (BMI measurement), there are three categories of nutritional status those are: severe underweight $(<17.0)$, mild-moderate underweight (17.0-18.4), ideal (18.5-25.0), overweight (25.1-27.0), severe overweight (>27.0). The value of the DMF-T is divided into five categories: incipient (0.0-1.1), mild (1.2-2.6), moderate (2.7-4.4), advanced (4.5-6.5), severe (>6.6). As for gingivitis using gingival index, namely: healthy if its value is 0 , mild inflammation if its value is $0.1-1.0$ value, moderate inflammation if its value is 1.1-2.0, severe inflammation if the value is 2.1-3.0. This is used to index the six teeth are the teeth 16 teeth 11 teeth 26 teeth 46,31 teeth, dental $36 .^{2,9}$

\section{Female}

\section{Results}

Based on the examination process, it shows that there are 37 children aged 9 (29.1\%), 10 children aged 10 (25.2\%), 43 children aged 12 or (33.9\%), 15 children aged 12 (11.8\%) figure 1.

There are 62 male $(48.8 \%)$ and 65 females (51.2) \% figure 2 . 


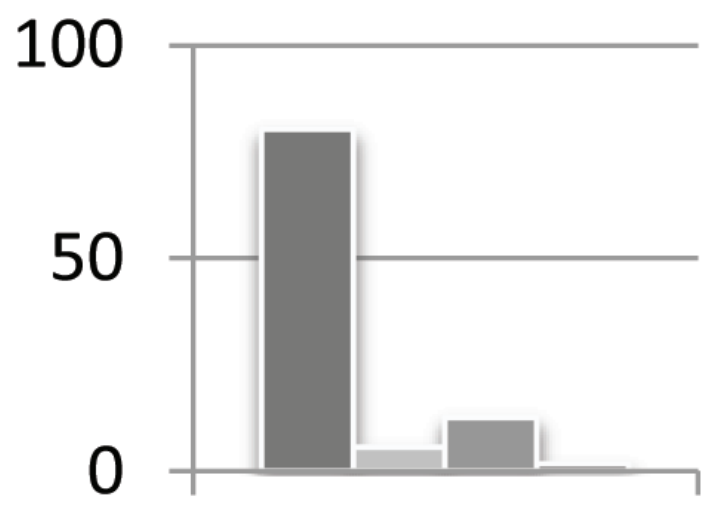

Nutritional status

Figure 3 Distribution of sample by nutritional status

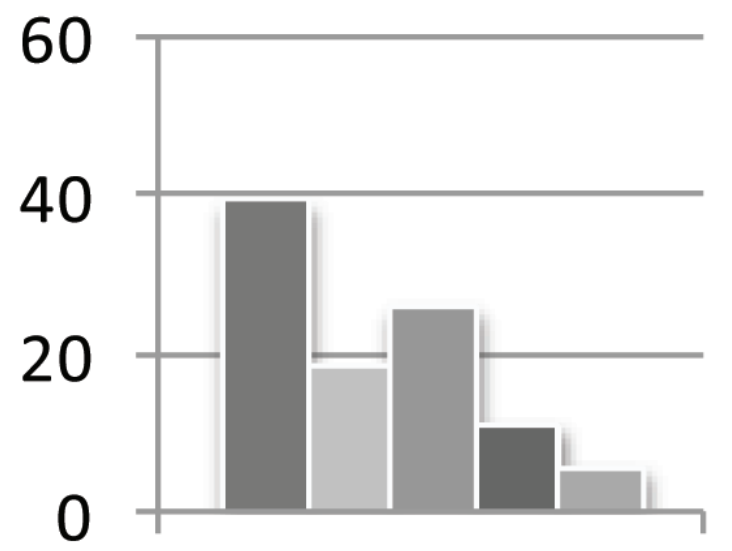

\section{Caries}

Figure 4 Distribution of sample by caries

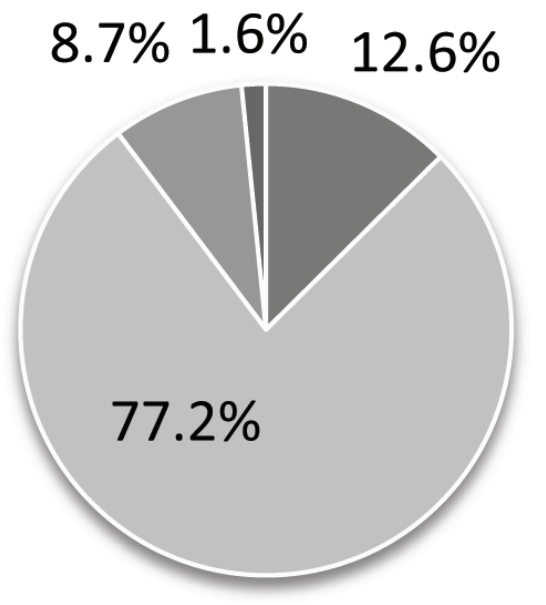

Figure 5 Distribution of sample by gingival index

The result from BMI measuring, there are 102 children who has severe underweight (80.3\%), 7 children who has moderate overweight (5.5\%),
16 children who has an ideal weight (12.6\%) and
Series1

Series2

Series3

Series4

Series2

Series3

Series4

Series5

Normal

/Healthy

Mild

Inflammation

Medium

Inflamation

Severe

Inflammation
2 children who has severe overweight (1.6\%) figure 3.

After DMF-T measuring, there is $39.4 \%$ who has incipient caries, $18.1 \%$ who has mild caries, $26.0 \%$ who has moderate caries, $11.0 \%$ who has advanced caries, and 5.5\% who has severe caries figure 4 .

After measure gingival index (GI), it shows that there are 16 children who has healthy gingival or none inflamation (12.6\%), 98 children who has mild (77.2\%), 11 children who has medium/ moderate inflammation $(8.7 \%)$ and 2 children who has severe inflammation (1.6\%) figure 5.

There is a relationship between nutritional status and gingivitis with dental caries figure 6-7.

\section{Discussion}

That sample aged 11 years-old is the biggest samples (43 children or 33.9\%), samples aged 9 years-old is 37 children or $29.1 \%$, samples aged 10 years old is 32 children or $25.2 \%$. The smallest number of samples is children aged 12 years-old is 15 children or $11.8 \%$. This various number of samples happened by accident because sample were selected by simple random sampling, which randomly selected. The result of this method is every research object of population have chance to be choosen as sample.

That there are 62 males $(48.8 \%)$ and 65 females $(51.2 \%)$. So, it was balance between male and female aged 9-12 years-old samples.

That samples who had severe underweight is the biggest number of sample with 102 children (80.3\%) and samples who had overweight is the smallest number of sample with 2 children (1.6\%). This result is same with previous research conducted by Abdul et al. ${ }^{3}$ in Jombang, which 21 samples are severe underweight and 2 samples are overweight. This situation influences by the nutrtition, dietary habit, or economic and social condition of society. ${ }^{3}$

That incipient caries is the biggest sample with 50 children (39.4\%), advanced caries is the smallest sample with 7 children (5.5\%). This condition is similar with the research conducted by Hana in Bojonegoro, shows that the biggest sample is children which has incipient caries with only 26 people or $(41.2 \%)$. It happened because the children are diligent to brush their teeth before sleep. ${ }^{4}$

That 98 samples who had mild inflammation $(77.2 \%)$ is the biggest samples and 2 samples who had severe inflammation (1.6\%) is the smallest number of sample. This case caused because most of the children is often and like to eat but they don't pay attention to oral hygiene. It was 


\begin{tabular}{|c|c|c|c|c|c|c|}
\hline \multirow[b]{3}{*}{ Nutritional Status } & \multicolumn{5}{|c|}{ Caries } & \multirow[b]{3}{*}{ p-value } \\
\hline & Incipient & Mild & Moderate & Advanced & Severe & \\
\hline & n (\%) & n (\%) & n (\%) & n (\%) & n (\%) & \\
\hline \multirow[t]{2}{*}{ Severe Underweight } & 39 & 18 & 29 & 11 & 5 & \multirow{10}{*}{$0.000^{*}$} \\
\hline & $(38.2 \%)$ & $(17.6 \%)$ & $(28.4 \%)$ & $(10.8 \%)$ & $(4.9 \%)$ & \\
\hline \multirow[t]{2}{*}{ Mild-Moderate Underweight } & 3 & 2 & 1 & 1 & 0 & \\
\hline & $(42.9 \%)$ & $(28.6 \%)$ & $(14.3 \%)$ & $(14.3)$ & $(0 \%)$ & \\
\hline \multirow[t]{2}{*}{ Ideal } & 8 & 3 & 3 & 2 & 0 & \\
\hline & $(50.0 \%)$ & $(18.8 \%)$ & $(18.8 \%)$ & $(12.5 \%)$ & $(0 \%)$ & \\
\hline \multirow[t]{2}{*}{ Overweight } & 0 & 0 & 0 & 0 & 2 & \\
\hline & $(0 \%)$ & $(0 \%)$ & $(0 \%)$ & $(0 \%)$ & $(100 \%)$ & \\
\hline \multirow[t]{2}{*}{ Total } & 50 & 23 & 33 & 14 & 7 & \\
\hline & $(39.4 \%)$ & $(18.1 \%)$ & $(26.0 \%)$ & $(11.0 \%)$ & $(5.5 \%)$ & \\
\hline
\end{tabular}

${ }^{\star}$ Chi-square test: $\mathrm{p}<0.05$; significant

Table 2 Relationship of Nutritional Status to Gingivitis

\begin{tabular}{|c|c|c|c|c|c|}
\hline \multirow[b]{3}{*}{ Nutritional Status } & \multicolumn{4}{|c|}{ Gingival Index } & \multirow[b]{3}{*}{ p-value } \\
\hline & None gingivitis & Mild gingivitis & Moderate & Severe & \\
\hline & n (\%) & n (\%) & n (\%) & n (\%) & \\
\hline \multirow[t]{2}{*}{ Severe Underweight } & 11 & 81 & 9 & 1 & \multirow{10}{*}{$0.000^{*}$} \\
\hline & $(10.8 \%)$ & $(79.4 \%)$ & $(8.8 \%)$ & $(1.0 \%)$ & \\
\hline \multirow[t]{2}{*}{ Mild-Moderate Underweight } & 2 & 4 & 1 & 0 & \\
\hline & $(28.6 \%)$ & $(57.1 \%)$ & $(14.3 \%)$ & $(0 \%)$ & \\
\hline \multirow[t]{2}{*}{ Ideal } & 3 & 13 & 0 & 0 & \\
\hline & $(18.8 \%)$ & $(81.3 \%)$ & $(0 \%)$ & $(0 \%)$ & \\
\hline \multirow[t]{2}{*}{ Overweight } & 0 & 0 & 1 & 1 & \\
\hline & $(0 \%)$ & $(0 \%)$ & $(50.0 \%)$ & $(50.0 \%)$ & \\
\hline \multirow[t]{2}{*}{ Total } & 16 & 98 & 11 & 2 & \\
\hline & $(12.6 \%)$ & $(77.2 \%)$ & $(8.7 \%)$ & $(1.6 \%)$ & \\
\hline
\end{tabular}

${ }^{*}$ Chi-square test: $\mathrm{p}<0.05$; significant

proved by calculus and plaque measurement shows that there is high amount of plaque.

Correlation test using chi-square test, shows value $p=0.000$ is smaller than $p=0.05$. It means there are correlation of nutritional status and the severity level of caries in school children aged 9-12 years old. The relationship of nutritional status and caries shows that children, who severe underweight, had higher odds for moderate caries $(38.2 \%)$ than others group of who has an ideal weight, had moderate caries (18.8\%). This case is not similar with the research conducted by Abdul and Agus in Jombang, with the result that there are many children with caries and bad nutritional status which 21 children $(77.8 \%)$ and following by the children with severe caries 22 children $(81.5 \%)$. It caused by consuming snack or unhealthy food that can increase the level of caries without brushing teeth. Abdul's opinion influenced by some factors, these are the impact of unbalance of intake and output or another disease. According to the research, nutritional status influenced by uncomfortable feeling because of bad condition of body such as dental caries, the object of dental caries in certain level can cause dental cavity which until pulp tissue and if there is food in those cavity it can occur uncomforted feeling and decreased the appetite of the children which is record as bad nutritional status of children. ${ }^{3}$

The relation of nutritional status to gingivitis shows that A group of who severe underweight (102 children), had higher odds for mild gingivitis (GI 79.4\%) than others group of who has an ideal weight (16 children), had mild gingivitis (GI 62.5\%). This case is similar with the research that conducted by Inaam in Irk stated that the level 
of gingivitis of people with bad nutrition is higher than group of people with overweight. It caused by the high number of calculus in the oral cavity, and economic and social condition. ${ }^{9}$ Social-economic influences plaque index because the behavior of children with bad nutrition, they don't know how to maintain their oral hygiene and bad nutrient may cause the weakness of immune system response and it may related to the increase of dental plaque. ${ }^{4}$

\section{Conclusion}

Based on the description above, the researcher can conclude that there is a relation of nutritional status to the gingivitis and dental caries severity among school children aged 9-12 years old and the children who has overweight, will has a high odd to severe dental caries. Also, there is a relation of nutritional status to gingivitis level among children aged 9-12 years old where people with an ideal weight, will has higher odds to mild inflammation of gingival.

\section{Conflict of Interest}

The authors report no conflict of interest.

\section{References}

1. Wulandari M, Sayono, Ulfa N. Hubungan konsumsi kalsium dalam makanan dan minuman dengan keparahan karies gigi pada murid kelas IV dan V SDN Melati Kidul 1 dan 2 Kudus. Jurnal unimus 2012: 1-2.

2. Hansen CHW, Dinar A, Wicaksana, et al. Gambaran status karies gigi anak usia 11-12 tahun pada keluarga pemegang jamkesmas di kelurahan Tumatangtang 1 kecamatan Tomohon Selatan 2013: 1.

3. Abdul G, Agus F. Hubungan gigi karies terhadap status gizi anak TK Muslimat 7 peterongan Jombang. Jurnal Edu Health 2012;2: 8-9.

4. Hana YK. Hubungan konsumsi makanan kariogenik dengan kejadian karies gigi dan status gizi pada anak kelas III dan IV SDN Kadipaten I dan II Kabupaten Bojonegoro. Universitas Diponogoro Semarang; 2013. p. 1-2.

5. Nirham A, Nursalim, Darmawan S. Faktor-faktor yang mempengaruhi kejadian karies gigi pada siswa kelas 1 di SD Negeri 1 Pekkae Kecamatan Tanete Rilau Kabupaten Barru. Jurnal Ilmiah Kesehatan Diagnosis 2014;4: 414-415.

6. Zakirah CP. Pengaruh maloklusi kelas i angle tipe modifikasi dewey terhadap prevalensi gingivitis pada siswa/i SMAN 3 Banda Aceh 2015.

7. Cindra, Gunawan P, Dinar A, et al. Gambaran status gingiva pada anak usia Sekolah Dasar di SD GMIM Tonsea Lama. Minahasa 2013;1.

8. Ika K, Oedijani S. Pengaruh paparan uap sulfur terhadap kejadian gingivitis studi pada pekerja tambang belerang di gunung welirang, Pasuruan, Jawa Timur. Semarang. Jurnal PDGI 2010;1: 25.

9. Inaam MS, Wesal AO. Periodontal condition in relation to nutritional status among kindergarten children in al-ramadi city/Iraq. Irak. Bagh College Dentistry 2013:26; 129-133.

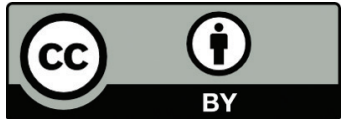

This work is licensed under a Creative Commons Attribution 